\title{
Stress and Diabetes Mellitus: Pathogenetic Mechanisms and Clinical Outcome
}

\author{
Diletta Maria Francesca Ingrosso ${ }^{a}$ Marina Primavera $^{a}$ Sona Samvelyan $^{b}$ \\ Veronica Maria Tagi ${ }^{a}$ Francesco Chiarelli ${ }^{a}$

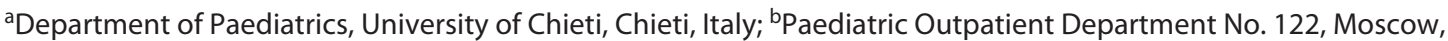 \\ Russia
}

\section{Keywords}

Stress - Type 1 diabetes - Type 2 diabetes

\begin{abstract}
Evidence suggests that psychological and physical stress are relevant triggering factors for the onset of type 1 diabetes (T1D) and type 2 diabetes (T2D). The underlying mechanisms involve a complex neuroendocrine structure, involving the central nervous system and the periphery. Psychological stress leads to an increase of serum glucocorticoid concentrations and catecholamines release increasing the insulin need and the insulin resistance. According to the $\beta$-cell stress hypothesis, also causes of increased insulin demand, such as rapid growth, overweight, puberty, low physical activity, trauma, infections, and glucose overload, are potentially relevant factors in development of T1D. It has also been demonstrated that chronic stress and obesity form a vicious circle which leads to a definitive metabolic failure, increasing the risk of developing T2D. In this review, we will provide the most recent data concerning the role of stress in the outcomes of T1D and T2D, with a focus on the role of physical and psychological stress on the onset of T1D.
\end{abstract}

(c) 2022 S. Karger AG, Base

Karger@karger.com www.karger.com/hrp

(C) 2022 S. Karger AG, Base

Karger"

\section{Introduction}

Stress is defined as a biological response evoked by any intrinsic or extrinsic stimulus [1]. The capacity to face adaptive stress responses, in an evolutionary perspective, is considered important for a successful outcome [2]. The so-called fight or flight response, i.e., a catabolic, antireproductive, anti-growth, and immunosuppressive plethora of mechanisms, is transient and in favor of survival [2-4]. However, chronic stress can make these effects detrimental by prolonging their duration, playing a major role in human diseases, and acting as a triggering or aggravating factor. Moreover, behavioral changes commonly seen in chronic stress disorders, such as a sedentary lifestyle and dietary habits (e.g., increased portion size, comfort eating, and alcohol consumption) may lead to weight gain and to abnormalities of glucose and lipid metabolism [4].

The stress system consists in a complex neuroendocrine structure, involving the central nervous system and the periphery [2]. Glucocorticoids (GC) and catecholaminas, respectively, final mediators of hypotalamic-pitu-

Diletta Maria Francesca Ingrosso, Marina Primavera, Sona Samvelyan, and Veronica Maria Tagi contributed equally to the manuscript.

Correspondence to:

Francesco Chiarelli, chiarelli@ unich.it 


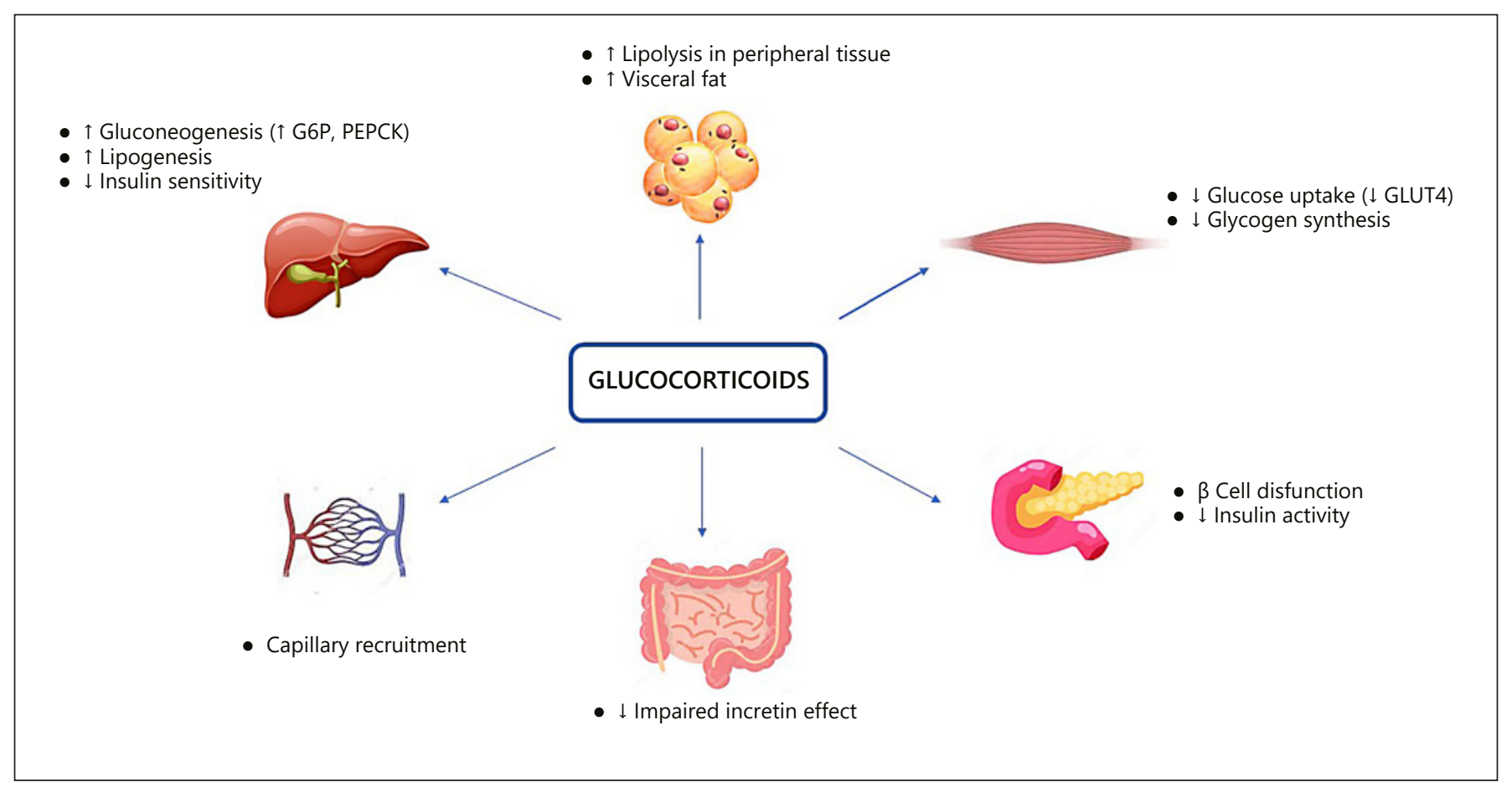

Fig. 1. Main effects of glucocorticoids on different organs and tissues.

itary-adrenal-axis and sympathetic nervous system, are the main hormonal effectors of the stress system: while during acute stress the whole body metabolism may not be affected, when chronically stimulated, the stress hormones can cause deleterious effects on glucose homeostasis. More specifically, during an acute stress event, glucose concentration and insulin secretion increases, so that glucose disposal is stimulated, and normoglycemia is maintained. When the stressor is chronic, the process becomes allostatic (literally "stable through change"). Stumvoll et al. [5] in 2003 first used the term "glucose allostasis," referring to a process where, during a chronic stress situation such as insulin resistance, glucose do not return to the initial concentration, in order to continuously inform the $\beta$-cell that insulin resistance is present; for this reason, chronic insulin resistance is accompanied by an increase in glycemia (leading to the development of type 2 diabetes [T2D]) even in the presence of normal beta-cell function.

\section{Effects of GC}

GC are so named because of their recognized actions on carbohydrate metabolism [6,7]. Figure 1 synthesizes the main effects of GC on different organs and tissues. In order to recruit all available energy resources to defend body homeostasis, GC stimulate hepatic gluconeogenesis and glycogen storage [6]; GC also reduce glucose uptake and utilization in skeletal muscle and white adipose tissue, so that hyperglycemia is the most rapid-onset and common effect associated with their hyperstimulation and their use as drugs [7-9]. Chronic stress, via prolonged hypercortisolemia, can progressively lead to visceral fat accumulation, decreased lean body mass, and insulin resistance.

Particularly, GC increase endogenous glucose production in the liver directly by activating numerous genes involved in hepatic glucose metabolism, such as phosphoenolpyruvate carboxykinase and glucose-6-phosphatase [10-13]. Indirectly, GC antagonize the metabolic actions of insulin $[14,15]$. Hepatic gluconeogenesis is also enhanced by the effects of GC on other counterregulatory hormones such as glucagon and epinephrine [16].

In skeletal muscle and other peripheral tissues, GC reduce glucose uptake, directly antagonizing insulin signaling cascade. GLUT 4 transporter is the major determinant of insulin-dependent peripheral glucose uptake; it is mainly expressed in skeletal muscle and is increased by insulin $[17,18]$. In these tissues, GLUT 4 expression is also increased by GC, but its translocation to the cell sur- 
face in response to insulin and to other stimuli (e.g., hypoxia) is inhibited in presence of GC $[6,18,19]$, leading to a decrease in glucose uptake.

In white adipose tissue, GC increase lypolisis to provide glycerol as a precursor for gluconeogenesis, so that the non-esterified fatty acids can accumulate within muscle cells and again reduce glucose uptake by interfering insulin signaling. In pancreas, costicosteroids also inhibit the production and secretion of insulin from $\beta$ cells $[20$, 21].

\section{Sympathoadrenal System}

It is also well established that the increased sympathoadrenal system activity during chronic stress can contribute to impaired glucose tolerance and increased risk for acute cardiovascular events [5, 22-26]; this metabolic response is directly related to the $\beta 2$ adrenoceptor activity [26]. Wolfe et al. [27] first demonstrated that, under physiologic conditions, infusing catecholamines is associated with enhanced aerobic glycolysis, glucose release from glycogenolysis and gluconeogenesis, and inhibition of insulin-mediated glycogenesis, resulting in hyperglycemia and hyperlactatemia [26, 28]. Moreover, shock states (characterized by compromised tissue microcirculatory perfusion and mytochondrial dysfunction) often correlate with hypermetabolic state, insulin resistance, and increased oxygen demands [27].

Epinephrine and norepinephrine contribute to insulin resistance by activating $\beta$ adrenergic receptors (AR). Interestingly, activation of $\beta$ AR in cardiomyocites, adypocites, and endothelial cells can lead to oxidative stress by $\beta 2$ AR mediated NOX upregulation [29-31]; in adipocites, the $\beta 3 \mathrm{AR}$ activates the hormone-sensitive lipase which promotes the accumulation of free fatty acids and the associated increase in MAPK activation and ceramide synthesis [32]. It is well known that ceramide promotes insulin resistance by inhibiting the activity of Akt/PKB [33].

\section{Immune Responses}

Chronic stress also plays a immunomodulatory role. Innate and adaptive immune responses can be suppressed or dysregulated by the capacity of stress to alter the Type 1 - Type 2 cytokine balance; GC can alter leukocyte traffic and function, decrease the production of cytokines and mediators of inflammation, and inhibited the latter's effects on target tissues $[4,34]$. On the other hand, cytokines and other humoral mediators of inflammation are powerful activators of the central stress response, forming a feedback loop through which the immune/inflamma- tory system communicates with the hypotalamic-pituitary-adrenal-axis [34], especially IL-6 [35]. This lowgrade inflammatory state is a pathogenetic element in common with obesity [36]; as weight gain progresses, adipocytes constantly secrete adipokines and chemokines in the systemic circulation, chemoattracting and recruiting macrophages, which, in response, release locally cytokines (e.g., TNF-a and IL-6) [36, 37].

\section{Type 1 DM versus Type 2 DM}

Evidence suggests that psychological and physical stress are relevant triggering factors for the onset of type 1 diabetes (T1D) and T2D. The onset of T1D is particularly linked to the beta-cell stress hypothesis, involved in an autoimmune mechanism that will be described later in this paper. Regarding T2D, it has been demonstrated that chronic stress and obesity form a vicious circle which leads to a definitive metabolic failure, increasing the risk of developing T2D. This review highlights the main pathophysiologic mechanisms which link chronic stress to metabolic failure, particularly insulin resistance, T1D and T2D.

\section{Stress and Type 2 Diabetes}

Indeed, we can certainly affirm that chronic stress and obesity form a vicious circle which leads to a definitive metabolic failure. The endpoint of this metabolic failure is the development of T2D. Several studies have shown that acute stress events could contribute to the expression of hyperglycemia and type II diabetes in animal models: Mikat et al. [38] demonstrated that a stressful situation, such as an esophageal intubation, on sand rats maintained on a low-calorie, low-carbohydrate diet of vegetables and saline, can lead to an abnormal glucose tolerance typical of type II diabetes. Similar data have been reported in genetically obese mouse (C57BL76J, ob/ob) [39], where stress consisted of restraint in a wire-mesh cage for $60 \mathrm{~min}$, punctuated by a 5 -min period of shaking. In general, the exaggerated glycemic responses of ob/ob mice to stress correlates with a sympathetic discharge, consisting in an increased level of catecholamines. In humans, an exaggerated glycemic reactivity to behavioral stress also appears to be characteristic of individuals predisposed to developing type II diabetes. For instance, $60 \%$ of Pima Indians eventually develop type II diabetes during adulthood: interestingly, they showed a disturbed glycemic response to behavioral stress compared with whites [40]. More recently, another study was performed in 30 adult
Horm Res Paediatr 2023;96:34-43 DOI: $10.1159 / 000522431$
Ingrosso/Primavera/Samvelyan/Tagi/ Chiarelli 
patients with T2D [41], exposed to moderate psychosocial stress by means of the Trier Social Stress Test applied in the postprandial state; the effect of acute psychological stress was assessed on glucose concentrations in the fasting and postprandial state. Glucose concentrations were statistically significantly higher compared with the control nonstress day. In the fasting state, glucose concentrations decreased slightly during the control day but remained stable on the stress-test day. Finally, all these studies suggest that the link between stress and the development of type II diabetes is an abnormal glucose response due to an increased activity of the autonomic nervous system, particularly an $\alpha$-adrenergic stimulation.

Also another "chronic stress disorder," such as depression, appears to increase the risk of T2D by $60 \%$ [42]. The Hoorn Study [43] also showed that major stressful life events during a preceding 5-year period are associated with undetected T2D and visceral adiposity. Interestingly, as Butler [44] reported, the disparities in social determinants of health play an important role in youth-onset T2D.

Recently, relevant evidence supporting the "developmental programming" of $\mathrm{T} 2 \mathrm{D}$, specifically by the intrauterine environment, have emerged [45]. Human and animal studies and insights form natural historical events, such as the Dutch Hunger Winter, the Chinese famine, and the Quebec Ice Storm, allowed to detect several potential epigenetic mechanisms in the development of T2D. In the children of mothers who experienced hardship and stress during the ice storm, higher secretion of insulin [46] and C-peptide [47] were observed. A longitudinal showed that children who were prenatally exposed to bereavement had a major risk of developing T2D diagnosis later in life [48]. In murine models, it has been observed that prenatal stress increases rat offspring susceptibility to diet-induced obesity [49] and that maternal sleep fragmentation-induced stress leads to metabolic disorders in offspring, including increased body weight, visceral fat mass, and HOMA-IR [50].

\section{Psychological Stress and Type 1 Diabetes}

\section{Stress as a Triggering Event for T1D}

T1D is a chronic autoimmune disease characterized by destruction of pancreatic beta cells leading to hyperglycemia and to an insulin-dependent state lifelong. Many factors, such as infections, diet, vitamin D deficiency, intestinal microbiota are proposed as environmental stressors able to trigger the onset of T1D in individuals at genetic risk. Among possible trigger factors of T1D, psychological stress has also been proposed [51], due to an increase of serum glucocorticoid concentrations and catecholamines, which increase the insulin need and the insulin resistance. In this way, the stress has been proposed as a trigger of T1D. This is known as "beta cell stress hypothesis" [52, 53]. In addition, it is well established that an increased production of pro-inflammatory cytokine, such as IL-1 $\beta$ [54], is present in autoimmune disorders.

Several studies report the link between severe life events during childhood as potential risk for the development of T1D [55-63]. Sipetic et al. [62] have been conducted a case-control study comprising 105 children with T1D and 210 controls matched by age ( \pm 1 year), sex and place of residence to test the hypothesis that psychological dysfunction and stressful life events could increase the risk of developing T1D [62]. In this study health-related stressful events (hospitalization of participants, accidents), severe family events (close relative died, parents divorced), changes in family constellation (relative left home, new sibling, changes in the number of family members, change of dwelling), parents' job-related issues (parent changed job, parent lost job), school-related issues (enrollment in elementary school, change of school), other severe life events (severe accident, hospitalization or death of close friend, quarrels between parents, war in republics of former Yugoslavia), and other minor life events (conflicts with parents/teacher/neighbors, physical attack, lost in town, separation from parents, school examination) were all associated with significantly increased risk for developing TD1 [62]. In this study also, a multivariate logistic regression analysis has been conducted, and all factors remain significantly related to T1D except sleep disorders and school-related issues [62]. Sipetic et al. [62] noted that it was probable that social, psychological, physical triggers, causing an excessive release of catecholamines and cortisol, increased insulin requirements and then increased workload on the $\beta$-cells, precipitating the onset of T1D.

Although many studies report a positive association between T1D and stressors, Littorin et al. [64] conducted a patient-control study that does not support this hypothesis. This study was based on wide study (Diabetes Incidence Study in Sweden) of newly diagnosed patients [64]. All individuals aged 15-34 years of age were included. 349 diabetic patients and 979 control subjects were enrolled. A questionnaire was proposed to healthy subjects and to diabetic patients at 4 weeks after the diagnosis of T1D. The questionnaire was about: family history of diabetes in first degree relatives; social environment (including 
education level of parents and respondent), parental age at birth of respondent, living conditions, lifestyle and life events experienced in the last year, also auxological parameters were considered (height, weight, waist to hip ratio) [64]. The conclusions of this study did not support the hypothesis for which psychological stress favorite the onset of T1D, in fact diabetic patients had experienced fewer conflicts with their parents and had less often broken contacts with their friends than control subjects [64].

The limit of most of the studies reported in literature is the retrospective design. About that Nygren et al. [65] conducted a population-based prospective cohort study to investigate whether psychological stress occurred during childhood could be a risk factor for the onset of T1D. The All Babies In Southeast Sweden (ABIS) study invited all families with babies born between October 1, 1997, and September 30, 1999, in southeast Sweden to participate. A total of 10,495 participants at $2-3,5-6,8$, and 10-13 years of age not yet diagnosed with T1D were included; 58 children were afterward diagnosed between 3 and 14 years of age [65]. The questionnaire proposed to the family investigate psychological stress in the family, severe or negative life events for children and for parents, parenting stress and worries and parent's social support. This study concluded that serious life event experienced by the child during the first 14 years of life increased the risk of diagnosis of T1D regardless of heredity for T2D, size for gestational age, the parents' education level, whether the mother worked less than $50 \%$ of full time before the child's birth and the childhood BMI. If the child had experience of a serious life event, he has a risk three times higher to develop T1D before 14 years of age. It is important to mark that the heredity remains the main risk factor, increasing the risk of diabetes of about 4 times than a serious life event experience $[65,66]$.

The hypothesis that psychological stress would favorite the onset or the progression of T1D is really interesting, and this assumption paves the way for another prevention cue for T1D, but more empirical data are surely needed. Prospective and epidemiological studies are needed to support the causality relationship between psychological stressors and T1D, to examine a new potential risk factor of this chronic autoimmune disease. What is better known is that psychological stress can precipitate manifest $\mathrm{T} 1 \mathrm{D}$, although the biological mechanisms are still unknown.

\section{Stress and Metabolic Control in T1D}

Stress is not only a potential triggering factor for the onset of T1D, but it can also influence the outcomes of patients affected by T1D. Stress is common in children with T1D and their caregivers. Besides general life stress, patients with T1D experience additional diabetes-specific stress [67], because of daily self-management, adherence to the treatment regimen, etc.

Rechenberg et al. [66] conducted a randomized controlled trial among 320 adolescents with T1D aged 11-14 years to investigate the influence of general and diabetesspecific stress on $\mathrm{HbA1c}$ levels, self-management behaviors, and QOL. Over 50\% of the participants reported high levels of both general and disease-related stress. Furthermore, higher levels of both types of stress were negatively associated with higher levels of HbAlc, poorer self-management, and lower diabetes-specific QOL. At the same time, the diabetes-specific stress showed greater influence on the variance in $\mathrm{HbAlc}$, while general stress did not [66].

The course of $\mathrm{T} 1 \mathrm{D}$, as well as diabetes outcomes, is highly associated with the stress regulation in both patients and their caregivers [66]. The great responsibility regarding child's health causes numerous challenges for patient's family and is a source of parental stress. Parenting and parent-child interactions have a crucial role in achieving better glycemic control [66].

Costa-Cordella et al. [67] showed a significant association between child's diabetes outcomes and attachment strategies, which is a bio-behavioral system of stress regulation. There are two possible pathways: being activated by stress, attachment strategies help to regulate the stress response and promote psychosocial well-being, or, ineffective activation of attachment strategies, which is insufficient to handle stress, leads to chronic stress activation. In this regard, there are also some gender differences. In boys, maternal stress causes unfavorable diabetes outcomes, while in girls it is associated with better self-control due to early autonomy and more favorable outcomes, at least in the short term [67].

Self-management in children and adolescents with T1D is constant and complex, requiring active involvement of both patients and their caregivers [66]. Learning to cope with stressful events is an important factor in reaching better long-term outcomes of diabetes mellitus [67]. Jaser et al. [68] examined coping strategies in adolescents with T1D as predictors of adjustment and glycemic control. The results showed that higher levels of stress are associated with poorer use of adaptive coping strategies [68]. Primary control coping (e.g., problem-solving) and secondary control engagement coping (e.g., positive thinking) strategies lead to better quality of life and fewer depressive symptoms. In contrast, coping was not found to be a significant predictor of glycemic control [68].
38

Horm Res Paediatr 2023;96:34-43 DOI: $10.1159 / 000522431$
Ingrosso/Primavera/Samvelyan/Tagi/ Chiarelli 
Table 1. Physical potential triggers and protective factors for the progression to T1D

\begin{tabular}{|c|c|c|}
\hline & Trigger factors & Protective factors \\
\hline Prenatal factors & $\begin{array}{l}\text { Congenital rubella } \\
\text { Maternal enteroviral infection } \\
\text { Caesarean section } \\
\text { Higher birthweight } \\
\text { Older maternal age } \\
\text { Low maternal vegetables intake }\end{array}$ & $\begin{array}{l}\text { Higher maternal vitamin D intake or } \\
\text { concentration in late pregnancy }\end{array}$ \\
\hline Postnatal factors & $\begin{array}{l}\text { Enteroviral infections } \\
\text { Frequent respiratory or enteric infections } \\
\text { SARS-CoV-2 infections } \\
\text { Abnormal microbiome } \\
\text { Early exposure to } \\
\quad \text { Cereals } \\
\text { Root vegetables } \\
\text { Eggs and cow's milk } \\
\text { Infant weight gain }\end{array}$ & $\begin{array}{l}\text { Probiotics in the first month } \\
\text { Higher omega-3 fatty acids } \\
\text { Introduction of solid foods while } \\
\text { breastfeeding and after age } 4 \text { months }\end{array}$ \\
\hline $\begin{array}{l}\text { Factors influencing } \\
\text { progression }\end{array}$ & $\begin{array}{l}\text { Persistent or recurrent enteroviral infections } \\
\text { Overweight or increased weight velocity } \\
\text { High glycemic load, fructose intake } \\
\text { Dietary nitrates or nitrosamines } \\
\text { Puberty } \\
\text { Steroid treatment } \\
\text { Insulin resistance }\end{array}$ & Unknown \\
\hline
\end{tabular}

Factors written in bold type are the ones with the strongest evidence base.

\section{Physical Stress Triggers of Type 1 Diabetes}

Psychological factors are not the only source of stress responsible for the onset of T1D. Physical stress may represent a significant trigger too.

According to the $\beta$-cell stress hypothesis, rapid growth, overweight, puberty, low physical activity, trauma, infections, and glucose overload, all causes of increased insulin demand, are potentially relevant factors in development of T1D [69]. Prolonged endoplasmic reticulum stress impairs insulin synthesis and causes pancreatic $\beta$-cell apoptosis [70]. On the other hand, reduced insulin production relieves endoplasmic reticulum stress and induces $\beta$-cell proliferation [71]. Moreover, endoplasmic reticulum stress might increase abnormal post-translational modification of endogenous $\beta$-cell proteins [70].

Table 1 summarizes the principle prenatal and postnatal physical potential triggers and protective factors for the progression to T1D. In the following paragraphs, we will focus on two of the most studied and debated aspects of physical stress, reporting the most recent evidence in literature.

\section{Infections}

Regarding infections, several viruses have been studied, with enteroviruses having the strongest evidence from studies in animal models [69] and in human beings [72]. Bacterial infections are rarely discussed, although bacteria as a cause of pancreatic lesions cannot be excluded [72].

Virus-induced $\beta$-cell damage is due both to direct lytic effects of viral replication and host inflammatory response mediated damage by autoreactive $\mathrm{CD}+\mathrm{T}$ cells, leading to autoimmunity [72]. The most studied mechanism in the pathogenesis of chronic $\beta$-cell damage is molecular mimicry: viral epitope shares a resemblance with host islet protein causing crossreactivity and autoimmune $\mathrm{T}$ cell response against host tissue in susceptible individuals [72]. Nevertheless, evidence suggests that molecular mimicry might accelerate the autoimmune process once it is already started, rather than causing it first [73]. Other potentially responsible factors are bystander T-cell activation, the activation of a T-cell independent of an antigen-specific T-cell receptor stimulation, and bystander damage, in which $\beta$-cell destruction is accelerated by the pro-inflammatory cytokines released secondary to infection of adjacent pancreatic cells like al- 
pha, exocrine, endothelial, and neuronal cells [74, 75]. Inflammation state might lead to impaired glucose-mediated insulin release and delay in the conversion of proinsulin to insulin [72]. Another determinant element is that $\beta$-cells seem to be unable to clear viral infections, in comparison with $\alpha$-cells. Chronicity of $\beta$-cells infection is evident from postmortem studies in which viral capsid protein VP1 was expressed in the islets of $>60 \%$ T1D organ donors compared with non-T1D controls, among whom VP1 was expressed in only $8 \%$ [75]. The chronic infection causes persistent overexpression of $\mathrm{MHC}-1$ and therefore continuous presentation of $\beta$-cell epitopes to the immune system, facilitating autoimmunity [72].

Enteroviruses (e.g., coxsakievisurs) have a tropism to human pancreatic islets $[74,76]$ and have been detected in the pancreas of patients recently diagnosed with T1D. Enteroviral VP1 protein immunoreactivity in the $\beta$ cells of children with T1D is found more frequently than their age-matched controls [77-80] and $\beta$-cells expressing VP1 are more susceptible to apoptosis [81]. Furthermore, it has been postulated that enteroviral infections during pregnancy might lead to persistent infection and islet autoimmunity in the mother [82] and her offspring [83-85]; however, the pathogenesis of this event is still unknown.

Since the spread of COVID-19, many studies have focused on the ability of SARS-CoV-2 infection to cause T1D onset. A recent review [86] concludes that SARSCoV-2 can trigger severe diabetic ketoacidosis at presentation in individuals with new-onset diabetes. Nevertheless, no sufficient evidence that SARS-CoV-2 induces T1D is present until now. In fact, although infection-induced inflammation and cytokine activation lead to insulin resistance, which could cause stress hyperglycemia, it is uncertain to what extent the direct viral destruction of islet cells with impaired insulin production and release might be responsible for it [86].

Evidence suggests that several viral infections may contribute to autoimmunity at the basis of T1DM and do not only accelerate an existing autoimmune process. If this hypothesis was correct, identifying the viruses associated with the development of T1DM could be relevant for the development of preventive and curative therapies for this disease [87].

\section{Vaccines}

No association between vaccines and islet autoimmunity or T1D has been demonstrated since now [84-92]. Morgan et al. [92] conducted a meta-analysis of 23 studies investigating 16 vaccinations, concluding that vaccines in childhood do not increase the risk of T1D. Also the BCG vaccine, which seems to play a role in immune-modulation, has been demonstrated to have no association between BCG vaccination and T1D or islet autoimmunity by a Canadian study on a 20-year follow-up of the 1974 birth cohort, of which $45 \%$ were given BCG in the first year of life [93]. Case-control studies from Canada [94] and Sweden [95] and the Germany BABYDIAB study [89] showed concordant results.

Beyond their direct effect, it should be remembered that simultaneously with the decrease in infections in high-income countries, secondary to vaccination, the use of antibiotics, improved sanitation and socioeconomic status, an increased incidence of autoimmune diseases, type $1 \mathrm{DM}$ included, has been reported in the past 50 years. According to the hygiene hypothesis, this is explained by the fact that decreased microbial exposure in early childhood increases the risk of autoimmune diseases [87, 96-98]. This should be due to defective development of the regulatory T cells that produce TGF- $\beta$ and IL-10 and are able to prevent excessive innate and adaptive immune responses $[87,99,100]$; lack of microorganism-induced maturation of dendritic cells that improve the development of regulatory T cells [101]; and modifications in the gut microbiota [102]. In fact, viral infections in NOD mice trigger immunoregulatory mechanisms protecting against diabetes mellitus through both increasing the number of regulatory $\mathrm{T}$ cells and preventing expansion of diabetogenic CD8+ T cells $[103,104]$.

\section{Conclusion}

Several studies have demonstrated the link between potential psychological and physical stressor and the onset of T1D and T2D. Studies on animal models have shown that acute stress events could contribute to the expression of hyperglycemia and T2D. Similarly, in humans, an exaggerated glycemic reactivity to behavioral stress seems to predispose individuals to the development of T2D. The role of intrauterine events in determining insulin resistance in the offspring in later life is very interesting and should be studied in deep in order to program a targeted prenatal prevention.

The relationship between some triggering factors, such as enteroviral infections, infant weight gain, increased weight velocity and puberty, and T1D have a strong evidence base. Others factors, such as psychological stress, SARS-CoV-2 infections and abnormal microbiome need further studies in order to prove a certain association. Regarding vaccinations, no direct association
40

Horm Res Paediatr 2023;96:34-43 DOI: $10.1159 / 000522431$
Ingrosso/Primavera/Samvelyan/Tagi/ Chiarelli 
between vaccines and islet autoimmunity or T1D has been demonstrated since now, however it should be considered that decreased microbial exposure in early childhood, also due to vaccinations, increases the risk of autoimmune diseases as it is for T1D.

The time frame for the impact of stress on T1D is not completely understood, however, while psychological stress seems to precipitate manifest T1D, but no evidence is available regarding its direct role in autoimmunity, several studies suggest that some physical sources of stress, such as infections, may contribute directly to the autoimmune process. If this hypothesis was correct, identifying the viruses associated with the development of T1DM could be relevant for the development of preventive and curative therapies for this disease. Therefore, future studies should be aimed at clarifying the role of infections in the autoimmunity mechanism, in order to proceed with a preventive intervention.

\section{Conflict of Interest Statement}

F.C. is an Editorial Board Member in Hormone Research in Paediatrics.

\section{Funding Sources}

No funding was received for this study.

\section{Author Contributions}

D.I., M.P., S.S., and V.T. contributed equally to this paper. D.I., M.P., S.S., and V.T. drafted the manuscript and designed the figures. F.C. provided critical feedback and helped shaping the manuscript.

\section{References}

1 Yaribeygi H, Panahi Y, Sahraei H, Johnston TP, Sahebkar A. The impact of stress on body function: a review. EXCLI J. 2017 Jul 21;16: 1057-72.

2 Chrousos GP, Gold PW. The concepts of stress and stress system disorders. Overview of physical and behavioral homeostasis. JAMA. 1992 Mar 4;267(9):1244-52.

3 Selye $\mathrm{H}$. The general adaptation syndrome and the diseases of adaptation. J Clin Endocrinol Metab. 1946 Feb;6:117-230.

4 Kyrou I, Tsigos C. Stress hormones: physiological stress and regulation of metabolism. Curr Opin Pharmacol. 2009 Dec;9(6):787-93.

5 Stumvoll M, Tataranni PA, Stefan N, Vozarova B, Bogardus C. Glucose allostasis. Diabetes. 2003;52(4):903-9.

6 Kuo T, McQueen A, Chen TC, Wang JC. Regulation of glucose homeostasis by glucocorticoids. Adv Exp Med Biol. 2015;872:99-126.

7 Dallman MF, Strack AM, Akana SF, Bradbury MJ, Hanson ES, Scribner KA, et al. Feast and famine: critical role of glucocorticoids with insulin in daily energy flow. Front Neuroendocrinol. 1993 Oct;14(4):303-47.

8 Perez A, Jansen-Chaparro S, Saigi I, BernalLopez MR, Miñambres I, Gomez-Huelgas R. Glucocorticoid-induced hyperglycemia. J Diabetes. 2014 Jan;6(1):9-20.

9 Hwang JL, Weiss RE. Steroid-induced diabetes: a clinical and molecular approach to understanding and treatment. Diabetes Metab Res Rev. 2014 Feb;30(2):96-102.

10 McMahon M, Gerich J, Rizza R. Effects of glucocorticoids on carbohydrate metabolism. Diabetes Metab Rev. 1988 Feb;4(1):17-30

11 Vegiopoulos A, Herzig S. Glucocorticoids, metabolism and metabolic diseases. Mol Cell Endocrinol. 2007 Sep 15;275(1-2):43-61.
12 Jin JY, Dubois DC, Almon RR, Jusko WJ. Receptor/gene-mediated pharmacodynamic effects of methylprednisolone on phosphoenolpyruvate carboxykinase regulation in rat liver. J Pharmacol Exp Ther. 2004 Apr;309(1):328-39.

13 Vander Kooi BT, Onuma H, Oeser JK, Svitek CA, Allen SR, Vander Kooi CW, et al. The glucose-6-phosphatase catalytic subunit gene promoter contains both positive and negative glucocorticoid response elements. Mol Endocrinol. 2005 Dec;19(12):3001-22.

14 Zimmerman $\mathrm{T}$, Horber $\mathrm{F}$, Rodriguez $\mathrm{N}$, Schwenk WF, Haymond MW. Contribution of insulin resistance to catabolic effect of prednisone on leucine metabolism in humans. Diabetes. 1989 Oct;38(10):1238-44.

15 Andrews RC, Walker BR. Glucocorticoids and insulin resistance: old hormones, new targets. Clin Sci. 1999 May;96(5):513-23.

16 Dirlewanger M, Schneiter PH, Paquot N, Jequier E, Rey V, Tappy L. Effects of glucocorticoids on hepatic sensitivity to insulin and glucagon in man. Clin Nutr. 2000 Feb;19(1): 29-34.

17 Kuo T, Harris CA, Wang JC. Metabolic functions of glucocorticoid receptor in skeletal muscle. Mol Cell Endocrinol. 2013 Nov 5; 380(1-2):79-88.

18 Oda N, Nakai A, Mokuno T, Sawai Y, Nishida Y, Mano T, et al. Dexamethasone-induced changes in glucose transporter 4 in rat heart muscle, skeletal muscle and adipocytes. Eur J Endocrinol. 1995 Jul;133(1):121-6.

19 Dimitriadis G, Leighton B, Parry-Billings M, Sasson S, Young M, Krause U, et al. Effects of glucocorticoid excess on the sensitivity of glucose transport and metabolism to insulin in rat skeletal muscle. Biochem J. 1997 Feb 1; 321(Pt 3):707-12.
20 Weinstein SP, Wilson CM, Pritsker A, Cushman SW. Dexamethasone inhibits insulinstimulated recruitment of GLUT4 to the cell surface in rat skeletal muscle. Metabolism. 1998 Jan;47(1):3-6.

21 Boden G, Shulman GI. Free fatty acids in obesity and type 2 diabetes:defining their role in the development of insulin resistance and beta-cell dysfunction. Eur J Clin Invest. 2002 Jun;32(3):14-23.

22 Delaunay F, Khan A, Cintra A, Davani B, Ling ZC, Andersson A, et al. Pancreatic beta cells are important targets for the diabetogenic effects of glucocorticoids. J Clin Invest. 1997 Oct $15 ; 100(8): 2094-8$.

23 Grippo AJ, Johnson AK. Stress, depression and cardiovascular dysregulation: a review of neurobiological mechanisms and the integration of research from preclinical disease models. Stress. 2009 Jan;12(1):1-21.

24 Rozanski A, Blumenthal JA, Kaplan J. Impact of psychological factors on the pathogenesis of cardiovascular disease and implications for therapy. Circulation. 1999 Apr 27;99(16): 2192-217.

25 Beaudry JL, Riddell MC. Effects of glucocorticoids and exercise on pancreatic $\beta$-cell function and diabetes development. Diabetes Metab Res Rev. 2012 Oct;28(7):560-73.

26 Ogawa A, Johnson JH, Ohneda M, McAllister $\mathrm{CT}$, Inman L, Alam T, et al. Roles of insulin resistance and beta-cell dysfunction in dexamethasone-induced diabetes. J Clin Invest. 1992 Aug;90(2):497-504.

27 Wolfe RR, Shaw JH. Effect of epinephrine infusion and adrenergic blockade on glucose oxidation in conscious dogs. Metabolism. $1986 \mathrm{Jul} ; 35(7): 673-8$. 
28 Barth E, Albuszies G, Baumgart K, Matejovic M, Wachter U, Vogt J, et al. Glucose metabolism and catecholamines. Crit Care Med. 2007 Sep;35(9 Suppl):S508-18.

29 Onyango AN. Cellular stresses and stress responses in the pathogenesis of insulin resistance. Oxid Med Cell Longev. 2018 Jul; 2018(2018):4321714.

30 Mangmool S, Denkaew T, Parichatikanond $\mathrm{W}$, Kurose H. $\beta$-Adrenergic receptor and insulin resistance in the heart. Biomol Ther. 2017 Jan 1;25(1):44-56.

$31 \mathrm{Xu}$ Q, Dalic A, Fang L, Kiriazis H, Ritchie RH, Sim K, et al. Myocardial oxidative stress contributes to transgenic $\beta 2$-adrenoceptor activation-induced cardiomyopathy and heart failure. Br J Pharmacol. 2011 Mar;162(5): 1012-28.

32 Mottillo EP, Shen XJ, Granneman JG. Beta3adrenergic receptor induction of adipocyte inflammation requires lipolytic activation of stress kinases p38 and JNK. Biochim Biophys Acta. 2010 Sep; 1801(9):1048-55.

33 Reali F, Morine M, Kahramanoğullari O, Raichur S, Schneider HC, Crowther D, et al. Mechanistic interplay between ceramide and insulin resistance. Sci Rep. 2017 Jan 23;7: 41231.

34 Turnbull AV, Rivier CL. Regulation of the hypothalamic pituitary-adrenal axis by cytokines: actions and mechanisms of action. Physiol Rev.. 1999 Jan;79(1):1-71.

35 Tsigos C, Papanicolaou DA, Kyrou I, Defensor R, Mitsiadis CS, Chrousos GP. Dose-dependent effects of recombinant human interleukin-6 on glucose regulation. J Clin Endocrinol Metab. 1997 Dec;82(12):4167-70.

36 Hotamisligil GS. Inflammation and metabolic disorders. Nature. 2006 Dec 14;444(7121): 860-7.

37 Wellen KE, Hotamisligil GS. Obesity-induced inflammatory changes in adipose tissue. J Clin Invest. 2003 Dec;112(12):1785-8.

38 Mikat EM, Hackel DB, Cruz PT, Lebovitz HE. Lowered glucose tolerance in the sand rat (psammonys obesus) resulting from esophageal intubation. Proc Soc Exp Biol Med. 1972; 139:1390-1.

39 Surwit RS, Feinglos MN, Livingston EG, Kuhn CM, McCubbin JA. Behavioral manipulation of the diabetic phenotype in ob/ob mice. Diabetes. 1984;33:616-8.

40 Surwit RS, McCubbin JA, Feinglos MN, Esposito-Del Peunte A, Lillioja S. Glycemic reactivity to stress: a biologic marker for development of type 2 diabetes. Diabetes. 1990; 39(1):8A.

41 Faulenbach M, Uthoff H, Schwegler K, Spinas GA, Schmid C, Wiesli P. Effect of psychological stress on glucose control in patients with type 2 diabetes. Diabet Med. 2012;29:128-31.

42 Mezuk B, Eaton WW, Albrecht S, Golden SH. Depression and type 2 diabetes over the lifespan: a meta-analysis. Diabetes Care. 2008 Dec;31(12):2383-90.
43 Mooy JM, de Vries H, Grootenhuis PA, Bouter LM, Heine RJ. Major stressful life events in relation to prevalence of undetected type 2 diabetes: the Hoorn Study. Diabetes Care. 2000 Feb;23(2):197-201.

44 Butler AM. Social determinants of health and racial/ethnic disparities in type 2 diabetes in youth. Curr Diab Rep. 2017 Aug;17(8):60.

45 Fernandez-Twinn DS, Hjort L, Novakovic B, Ozanne SE, Saffery R. Intrauterine programming of obesity and type 2 diabetes. Diabetologia. 2019;62(10):1789-801.

46 Dancause KN, Veru F, Andersen RE, Laplante DP, King S. Prenatal stress due to a natural disaster predicts insulin secretion in adolescence. Early Hum Dev. 2013;89(9):773-6.

47 Cao-Lei L, Dancause KN, Elgbeili G, Laplante DP, Szyf M, King S. DNA methylation mediates the effect of maternal cognitive appraisal of a disaster in pregnancy on the child's Cpeptide secretion in adolescence: project ice storm. PLoS One. 2018;13(2):e0192199.

48 Virk J, Li J, Vestergaard M, Obel C, Kristensen JK, Olsen J. Prenatal exposure to bereavement and type-2 diabetes: a Danish longitudinal population based study. PLoS One. 2012;7(8): e43508.

49 Tamashiro KL, Terrillion CE, Hyun J, Koenig JI, Moran TH. Prenatal stress or high-fat diet increases susceptibility to diet-induced obesity in rat offspring. Diabetes. 2009;58(5): 1116-25.

50 Trzepizur W, Khalyfa A, Qiao Z, Popko B, Gozal D. Integrated stress response activation by sleep fragmentation during late gestation in mice leads to emergence of adverse metabolic phenotype in offspring. Metabolism. 2017;69:188-98.

51 Morse ZJ, Horwitz MS. Innate viral receptor signaling determines type 1 diabetes onset. Front Endocrinol. 2017 Sep 26;8:249.

52 Pallavicini F, Gaggioli A, Raspelli S, Cipresso $\mathrm{P}$, Serino S, Vigna C, et al. Interreality for the management and training of psychological stress: study protocol for a randomized controlled trial. Trials. 2013 Jun 28;14:191.

53 Ludvigsson J. Why diabetes incidence increases: a unifying theory. Ann N Y Acad Sci. 2006 Oct; $1079: 374-82$.

54 Grisanti LA, Evanson J, Marchus E, Jorissen H, Woster AP, DeKrey W, et al. Pro-inflammatory responses in human monocytes are beta1-adrenergic receptor subtype dependent. Mol Immunol. 2010 Mar;47(6):124454.

55 Stein SP, Charles E. Emotional factors in juvenile diabetes mellitus: a study of early life experience of adolescent diabetics. Am J Psychiatry. 1971 Dec;128(6):700-4.

56 Leaverton DR, White CA, McCormick CR, Smith P, Sheikholislam B. Parental loss antecedent to childhood diabetes mellitus. J Am Acad Child Psychiatry. 1980;19(4):678-89.

57 Siemiatycki J, Colle E, Campbell S, Dewar RA, Belmonte MM. Case-control study of IDDM. Diabetes Care. 1989 Mar;12(3):209-16.
58 Vialettes B, Ozanon J, Kaplansky S, Farnarier C, Sauvaget E, Lassmann-Vague V, et al. Stress antecedents and immune status in recently diagnosed type 1 (insulindependent) diabetes mellitus. Diabete Metab. 1989;15(1): $45-50$.

59 Hägglöf B, Blom L, Dahlquist G, Lönnberg G, Sahlin B. The Swedish childhood diabetes study: indications of severe psychologi- cal stress as a risk factor for type 1 (insulin-dependent) diabetes mellitus in childhood. Diabetologia. 1991 Aug;34(8):579-83.

60 Thernlund GM, Dahlquist G, Hansson K, Ivarsson S, Ludvigsson J, Sjöblad S, et al. Psychological stress and the onset of IDDM in children. Diabetes Care. 1995 Oct;18(10): 1323-9.

61 Vlajinac H, Sipetić S, Marinković J, Bjekić M, Kocev N, Sajić S. The Belgrade childhood diabetes study: comparison of children with type 1 diabetes with their siblings. Paediatr Perinat Epidemiol. 2006 May;20(3):238-43.

62 Sipetić S, Vlajinac H, Marinkovi J, Kocev N, Milan B, Ratkov I, et al. Stressful life events and psychological dysfunctions before the onset of type 1 diabetes mellitus. J Pediatr Endocrinol Metab. 2007 Apr;20(4):527-34.

63 Karavanaki K, Tsoka E, Liacopoulou M, Karayianni C, Petrou V, Pippidou E, et al. Psychological stress as a factor potentially contributing to the pathogenesis of type 1 diabetes mellitus. J Endocrinol Investig. 2008 May; 31(5):406-15.

64 Littorin B, Sundkvist G, Nyström L, Carlson A, Landin-Olsson M, Ostman J, et al. Family characteristics and life events before the onset of autoimmune type 1 diabetes in young adults: a nationwide study. Diabetes Care. 2001 Jun;24(6):1033-7.

65 Nygren M, Carstensen J, Koch F, Ludvigsson J, Frostell A. Experience of a serious life event increases the risk of childhood type 1 diabetes: the ABIS population-based prospective cohort study. Diabetotologia. 2015 Jun;58(6): 1188-97.

66 Rechenberg K, Whittemore R, Holland M, Grey M. General and diabetes-specific stress in adolescents with type 1 diabetes. Diabetes Res Clin Pract. 2017 Aug;130:1-8.

67 Costa-Cordella S, Luyten P, Giraudo F, Mena F, Shmueli-Goetz Y, Fonagy P. Attachment and stress in children with type 1 diabetes and their mothers. Rev Chil Pediatr. 2020 Feb; 91(1):68-75.

68 Jaser SS, Patel N, Xu M, Tamborlane WV, Grey M. Stress and coping predicts adjustment and glycemic control in adolescents with type 1 diabetes. Ann Behav Med. 2017; 51(1):30-8

69 Lamb MM, Yin X, Barriga K, Hoffman MR, Barón AE, Eisenbarth GS, et al. Dietary glycemic index, development of islet autoimmunity, and subsequent progression to type 1 diabetes in young children. J Clin Endocrinol Metab. 2008 Oct;93(10):3936-42. 
70 Cnop M, Foufelle F, Velloso LA. Endoplasmic reticulum stress, obesity and diabetes. Trends Mol Med. 2012 Jan;18(1):59-68.

71 Szabat M, Page MM, Panzhinskiy E, Skovsø S, Mojibian M, Fernandez-Tajes J, et al. Reduced insulin production relieves endoplasmic reticulum stress and induces $\beta$ cell proliferation. Cell Metab. 2016 Jan 12;23(1):17993.

72 Marré ML, James EA, Piganelli JD. $\beta$ cell ER stress and the implications for immunogenicity in type 1 diabetes. Front Cell Dev Biol. 2015 Oct 27;3:67.

73 Coppieters KT, Wiberg A, Tracy SM, von Herrath MG. Immunology in the clinic review series: focus on type 1 diabetes and viruses: the role of viruses in type 1 diabetes: a difficult dilemma. Clin Exp Immunol. 2012 Apr;168(1):5-11.

74 Stene LC, Rewers M. Immunology in the clinic review series; focus on type 1 diabetes and viruses: the enterovirus link to type 1 diabetes: critical review of human studies. Clin Exp Immunol. 2012 Apr;168(1):12-23.

75 Rewers M, Ludvigsson J. Environmental risk factors for type 1 diabetes. Lancet. 2016 Jun 4 387(10035):2340-8.

76 Boddu SK, Aurangabadkar G, Kuchay MS. New onset diabetes, type 1 diabetes and $\mathrm{CO}$ VID-19. Diabetes Metab Syndr. 2020 Nov; 14(6):2211-7.

77 Christen U, Edelmann KH, McGavern DB Wolfe T, Coon B, Teague MK, et al. A viral epitope that mimics a self antigen can accelerate but not initiate autoimmune diabetes. J Clin Invest. 2004;114(9):1290-8

78 Yoon JW, Austin M, Onodera T, Notkins AL. Isolation of a virus from the pancreas of a child with diabetic ketoacidosis. N Engl J Med. 1979 May;300(21):1173-9.

79 Tracy S, Drescher KM, Chapman NM. Enteroviruses and type 1 diabetes. Diabetes Metab Res Rev. 2011 Nov;27(8):820-3.

80 Richardson SJ, Willcox A, Bone AJ, Foulis AK, Morgan NG. The prevalence of enteroviral capsid protein vp1 immunostaining in pancreatic islets in human type 1 diabetes. Diabetologia. 2009 Jun;52(6):1143-51

81 Krogvold L, Edwin B, Buanes T, Frisk G, Skog $\mathrm{O}$, Anagandula $\mathrm{M}$, et al. Detection of a lowgrade enteroviral infection in the islets of langerhans of living patients newly diagnosed with type 1 diabetes. Diabetes. 2015 May; 64(5):1682-7.
82 Richardson SJ, Leete P, Bone AJ, Foulis AK, Morgan NG. Expression of the enteroviral capsid protein VP1 in the islet cells of patients with type 1 diabetes is associated with induction of protein kinase $\mathrm{R}$ and downregulation of Mcl-1. Diabetologia. 2013 Jan;56(1):18593.

83 RešićLindehammer S, Honkanen H, Nix WA, Oikarinen M, Lynch KF, Jönsson I, et al. Seroconversion to islet autoantibodies after enterovirus infection in early pregnancy. Viral Immunol. 2012 Aug;25(4):254-61.

84 Dahlquist GG, Ivarsson S, Lindberg B, Forsgren M. Maternal enteroviral infection during pregnancy as a risk factor for childhood IDDM. A population-based case-control study. Diabetes. 1995 Apr;44(4):408-13.

85 Viskari H, Knip M, Tauriainen S, Huhtala H, Veijola R, Ilonen J, et al. Maternal enterovirus infection as a risk factor for type 1 diabetes in the exposed offspring. Diabetes Care. 2012 Jun;35(6):1328-32.

86 Ceriello A, De Nigris V, Prattichizzo F. Why is hyperglycaemia worsening COVID-19 and its prognosis? Diabetes Obes Metab. 2020 Oct;22(10):1951-2.

87 Op de Beeck A, Eizirik DL. Viral infections in type 1 diabetes mellitus: why the $\beta$ cells? Nat Rev Endocrinol. 2016 May;12(5):263-73.

88 Graves PM, Barriga KJ, Norris JM, Hoffman MR, Yu L, Eisenbarth GS, et al. Lack of association between early childhood immunizations and beta-cell autoimmunity. Diabetes Care. 1999 Oct;22(10):1694-7.

89 Hummel M, Füchtenbusch M, Schenker M, Ziegler AG. No major association of breastfeeding, vaccinations, and childhood viral diseases with early islet autoimmunity in the German BABYDIAB Study. Diabetes Care. 2000 Jul;23(7):969-74.

90 Jefferson T, Demicheli V. No evidence that vaccines cause insulin dependent diabetes mellitus. J Epidemiol Community Health. 1998 Oct;52(10):674-5.

91 Offit PA, Hackett CJ. Addressing parents concerns: do vaccines cause allergic or autoimmune diseases? Pediatrics. 2003 Mar 111(3):653-9.
92 Morgan E, Halliday SR, Campbell GR, Cardwell CR, Patterson CC. Vaccinations and childhood type 1 diabetes mellitus: a meta-analysis of observational studies. Diabetologia. 2016 Feb;59(2):237-43.

93 Rousseau MC, El-Zein M, Conus F, Legault L, Parent ME. Bacillus Calmette-Guérin (BCG) vaccination in infancy and risk of childhood diabetes. Paediatr Perinat Epidemiol. 2016;30:141-8.

94 Parent ME, Siemiatycki J, Menzies R, Fritschi L, Colle E. Bacille Calmette-Guérin vaccination and incidence of IDDM in Montreal, Canada. Diabetes Care. 1997;20:767-72.

95 Dahlquist G, Gothefors L. The cumulative incidence of childhood diabetes mellitus in Sweden unaffected by BCG-vaccination. Diabetologia. 1995;38:873-4.

96 Strachan DP. Hay fever, hygiene, and household size. BMJ. 1989;299:1259-60.

97 Kamradt T, Göggel R, Erb KJ. Induction, exacerbation and inhibition of allergic and autoimmune diseases by infection. Trends Immunol. 2005;26:260-7.

98 Kondrashova A, Seiskari T, Ilonen J, Knip M, Hyöty H. The "Hygiene hypothesis" and the sharp gradient in the incidence of autoimmune and allergic diseases between Russian Karelia and Finland. APMIS. 2013;121: 478-93.

99 Bach JF, Chatenoud L. The hygiene hypothesis: an explanation for the increased frequency of insulin dependent diabetes. Cold Spring Harb Perspect Med. 2012;2:a007799.

100 Lehuen A, Diana J, Zaccone P, Cooke A. Immune cell crosstalk in type 1 diabetes. Nat Rev Immunol. 2010;10:501-13.

101 Rook GA, Brunet LR. Old friends for breakfast. Clin Exp Allergy. 2005;35:841-2.

102 Gulden E, Wong FS, Wen L. The gut microbiota and type 1 diabetes. Clin Immunol. 2015;159:143-53

103 Christen U, Benke D, Wolfe T, Rodrigo E, Rhode A, Hughes AC, et al. Cure of prediabetic mice by viral infections involves lymphocyte recruitment along an IP 10 gradient. J Clin Invest. 2004;113:74-84.

104 Filippi CM, Estes EA, Oldham JE, von Herrath MG. Immunoregulatory mechanisms triggered by viral infections protect from type 1 diabetes in mice. J Clin Invest. 2009; 119:1515-23. 